\title{
Crystal Structure and Cyclic Voltammetric Studies on the Metal Complexes of $N$-(Dimethylcarbamothioyl)-4-fluorobenzamide
}

\author{
Gun Binzet, ${ }^{1}$ Ersan Turunc, ${ }^{2}$ Ulrich Flörke, ${ }^{3}$ Nevzat Külcü, ${ }^{4}$ and Hakan Arslan $\left(\mathbb{D}{ }^{4}\right.$ \\ ${ }^{1}$ Department of Elementary Science Education, Faculty of Education, Mersin University, 33160 Mersin, Turkey \\ ${ }^{2}$ Advanced Technology Research and Application Center, Mersin University, 33343 Mersin, Turkey \\ ${ }^{3}$ Department of Chemistry, Paderborn University, 33098 Paderborn, Germany \\ ${ }^{4}$ Department of Chemistry, Faculty of Arts and Science, Mersin University, 33343 Mersin, Turkey
}

Correspondence should be addressed to Hakan Arslan; hakan.arslan@mersin.edu.tr

Received 31 October 2017; Accepted 26 December 2017; Published 30 April 2018

Academic Editor: Artur M. S. Silva

Copyright (C) 2018 Gun Binzet et al. This is an open access article distributed under the Creative Commons Attribution License, which permits unrestricted use, distribution, and reproduction in any medium, provided the original work is properly cited.

\begin{abstract}
We synthesized $\mathrm{N}$-(dimethylcarbamothioyl)-4-fluorobenzamide compound and its copper(II) and nickel(II) complexes. The structures of compounds have been characterized by elemental analysis and spectral data (IR, ${ }^{1} \mathrm{H}$ NMR). Furthermore, crystal and molecular structure of the synthesized complexes have been identified by using single crystal X-ray diffraction data. In the complexes formation the metal atom was coordinated via two sulfur atoms and two oxygen atoms. The single crystal structure of copper(II) and nickel(II) complex exhibits slightly distorted square planar geometry. The oxygen atoms are in a cis configuration. It appeared that the lengths of the thiocarbonyl and carbonyl bonds are longer than the average for $\mathrm{C}=\mathrm{S}$ and $\mathrm{C}=\mathrm{O}$; meanwhile the $\mathrm{C}-\mathrm{N}$ bonds in the complex ring appeared to be shorter than the average for $\mathrm{C}-\mathrm{N}$ single bonds. These data show that C-O, C-S, and $\mathrm{C}-\mathrm{N}$ bond lengths of the complexes suggest considerable electronic delocalization in the chelate ring. All bond lengths and angles obtained as a result of the analyses are found to be within experimental error limits. The obtained crystal analysis data shows that the structure of complex compounds is compatible with similar compounds in literature. Electrochemical behavior of complexes has been investigated by cyclic voltammetry technique in aprotic media. From the cyclic voltammetric investigation, both of the complexes have demonstrated electroactive properties.
\end{abstract}

\section{Introduction}

Benzoylthiourea derivatives are considered privileged compounds, because of their simple preparation with high yields [1-7]. The synthesis of new benzoylthiourea compounds also becomes widespread due to their potential application in biological [8-12] and analytical chemistry [13-17]. The ability of thiourea derivatives to complex with transition metal cations is well known $[18,19]$. In general, thiourea derivative ligands consist of some substituents with different electrondonating or electron withdrawing groups and, therefore, may have interesting electrochemical properties. Due to these properties, the studies on the electrochemical properties of benzoyl thiourea derivatives are found in literature, albeit to a lesser extent [20-28]. The presence of hard O- and $\mathrm{N}$ - and soft S-donor atoms in the backbones of these ligands enables them to react readily with both, transition group and main group metal ions, yielding stable metal complexes [29]. The present paper reports the synthesis, characterization, and electrochemical properties on copper(II) and nickel(II) complexes of $N$-(dimethylcarbamothioyl)-4fluorobenzamide compounds.

\section{Experimental}

2.1. Chemicals. All chemicals used in present study such as 4-fluorobenzoyl chloride, potassium thiocyanate, dimethyl amine, hydrochloric acid, nickel acetate, copper acetate, sodium hydroxide, tetrabutylammonium hexafluorophosphate, dichloromethane, and ethanol were purchased from Merck. All solvents and chemicals were of reagent grade quality and used without further purification. 
<smiles>CN(C)C(=S)NC(=O)c1ccc(F)cc1</smiles>

FIGURE 1

2.2. Instrumentation. $\mathrm{C}, \mathrm{H}$, and $\mathrm{N}$ analyses were carried out on a Carlo Erba MOD 1106 instrument. FT-IR (KBr pellets) spectra were recorded on a Shimadzu 435 spectrophotometer between 4000 and $400 \mathrm{~cm}^{-1}$. ${ }^{1} \mathrm{H}$ NMR spectra were recorded on a Bruker DPX 300 spectrometer, using $\mathrm{CDCl}_{3}$ as solvent and TMS as internal standard. Single crystal X-ray diffraction data were collected on a Bruker AXS SMART APEX CCD diffractometer using monochromated $\operatorname{MoK} \alpha(\lambda=0.71073 \AA)$ radiation. The structures were solved by direct and conventional Fourier methods [30]. Full-matrix least-squares refinement was based on $F^{2}$ and hydrogen atoms derived from difference maps and refined at idealized positions riding at their parent $\mathrm{C}$ atoms [31]. Cyclic voltammetry experiments were carried out using a $\mathrm{CHI} 660 \mathrm{E}$ electrochemical workstation.

2.3. Synthesis of the Ligand. N-(Dimethylcarbamothioyl)-4fluorobenzamide compound was synthesized according to literature $[18,19]$. A solution of 4-fluorobenzoyl chloride $(0.5 \mathrm{~mol})$ in dry acetone $(30 \mathrm{~mL})$ was added dropwise to a solution of potassium thiocyanate $(0.5 \mathrm{~mol})$ in dry acetone $(30 \mathrm{~mL})$. The reaction mixture was heated under reflux for $1 \mathrm{~h}$ and then cooled to room temperature. The dimethyl amine $(0.1 \mathrm{~mol})$ was added dropwise by stirring to the solution of 4-fluorobenzoyl isothiocyanate $(0.1 \mathrm{~mol})$ in dry acetone $(30 \mathrm{~mL})$. The reaction mixture was heated under reflux for $1 \mathrm{~h}$. Then, the mixture was poured into cold $0.1 \mathrm{M} \mathrm{HCl}$ acid solution. Then, the white precipitated solid compound was filtered. After that crystallization of the crude product by using a mixture of dichloromethane : ethanol (in 1:2 ratio by volume) gave $N$-(dimethylcarbamothioyl)-4fluorobenzamide as white crystals in $78 \%$ yield $[18,19]$.

N-(Dimethylcarbamothioyl)-4-fluorobenzamide, HL (See Figure 1). Color: White. Yield: $78 \%$. M.p.: $130-132^{\circ} \mathrm{C}$. Anal. calcd. for $\mathrm{C}_{10} \mathrm{H}_{11} \mathrm{FN}_{2} \mathrm{OS}(226.3 \mathrm{~g} / \mathrm{mol})$ : C, 53.08; H, 4.90; N, 12.38 . Found: C, 53.00; H, 4.81; N, 12.36\%. FT-IR (KBr, $\left.v, \mathrm{~cm}^{-1}\right): v$ $(\mathrm{NH}) 3231 ; \nu(\mathrm{CH}) 2998,2976,2936 ; \nu(\mathrm{C}=\mathrm{O}) 1668 ; \nu(\mathrm{C}=\mathrm{S})$ 1251, v (C-F) 758. ${ }^{1} \mathrm{H}$ NMR (300 MHz, $\mathrm{CDCl}_{3}, \delta$, ppm): 8.58 (s, 1H, N-H), 7.74 (d, 2H, Ar-H), 7.64 (d, 2H, Ar-H), 3.51 (s, $\left.3 \mathrm{H}, \mathrm{N}-\mathrm{CH}_{3}\right), 3.26$ (s, $3 \mathrm{H}, \mathrm{N}-\mathrm{CH}_{3}$ ).

2.4. Synthesis of the Metal Complexes. Complex compounds were prepared according to the method described in literature $[18,19,29,32,33]$. A metal acetate solution in methanol was added dropwise to the ligand in a 1:2 molar ratio in methanol. Then, the $\mathrm{pH}$ was adjusted with $0.1 \mathrm{M}$ $\mathrm{NaOH}$ or $0.1 \mathrm{M} \mathrm{HCl}$ for complex formation. The reaction mixture was stirred for $2 \mathrm{~h}$ at room temperature. The colored solid complexes were filtered and recrystallized from ethanol: dichloromethane $(1: 2, v: v)$ mixture $[18,19]$.<smiles>CN(C)C1=NC(c2ccc(F)cc2)=N[N+]2(O1)OC(c1ccc(F)cc1)N=C(N(C)C)S2</smiles>

Figure 2<smiles></smiles>

FIGURE 3

Bis(N,N-dimethyl-N'-4-fluorobenzoylthioureato) Nickel(II) $\left(\mathrm{NiL}_{2}\right)$ (See Figure 2). Color: Purple. Yield: 86 \%. M.p.: 257$258^{\circ} \mathrm{C}$. Anal. calcd. for $\mathrm{C}_{20} \mathrm{H}_{20} \mathrm{~F}_{2} \mathrm{~N}_{4} \mathrm{NiO}_{2} \mathrm{~S}_{2}$ (509.2 g/mol): C, 47.17; H, 3.96; N, 11.00. Found: C, 47.10; H, 3.87; N, $11.01 \%$. FT-IR (KBr, v, cm $\left.{ }^{-1}\right): v(\mathrm{CH})$ 2929, 2853 (vw); $v(\mathrm{CN}) 1602$ (w); $v$ (C-O), 1495 (vs); $v$ (C-F), 760 (w). ${ }^{1} \mathrm{H}$ NMR (300 MHz, $\left.\mathrm{CDCl}_{3}, \delta, \mathrm{ppm}\right): 8.13(\mathrm{~m}, 4 \mathrm{H}, \mathrm{Ar}-\mathrm{H}), 7.06$ (m, 4H, Ar-H), 3.42 (s, $\left.6 \mathrm{H}, \mathrm{N}-\mathrm{CH}_{3}\right), 3.32\left(\mathrm{~s}, 6 \mathrm{H}, \mathrm{N}-\mathrm{CH}_{3}\right)$.

Bis(N,N-dimethyl-N'-4-fluorobenzoylthioureato) Copper(II) $\left(\mathrm{CuL}_{2}\right)$ (See Figure 3). Color: Green. Yield: 71 \%. M.p.: 209-210 C. Anal. calcd. for $\mathrm{C}_{20} \mathrm{H}_{20} \mathrm{CuF}_{2} \mathrm{~N}_{4} \mathrm{O}_{2} \mathrm{~S}_{2}$ (514.1 g/ mol): C, 46.73; H, 3.92; N, 10.90. Found: C, 46.61; H, 3.80; N, $10.77 \%$. FT-IR $\left(\mathrm{KBr}, v, \mathrm{~cm}^{-1}\right): v(\mathrm{CH}), 2926,2852(\mathrm{vw}) ; v$ (CN) $1600(\mathrm{w}), v(\mathrm{C}-\mathrm{O}) 1493(\mathrm{vs}) ; \nu(\mathrm{C}-\mathrm{F}) 761(\mathrm{w})$.

2.5. Cyclic Voltammetry. All experiments were conducted in $\mathrm{CH}_{2} \mathrm{Cl}_{2}$ with $0.10 \mathrm{M}$ tetrabutylammonium hexafluorophosphate as the supporting electrolyte. Electrochemical experiments were conducted in a three-component cell consisting of a $\mathrm{Pt}$ wire auxiliary electrode, a nonaqueous reference electrode $\left(\mathrm{Ag} / \mathrm{Ag}^{+}\right)$, and a glassy carbon (GC) as working electrode in the range of -0.4 to $+0.4 \mathrm{~V}$ and -0.4 to $+1.6 \mathrm{~V}$ for $\mathrm{Cu}(\mathrm{II})$ and $\mathrm{Ni}(\mathrm{II})$ ions, respectively.

\section{Results and Discussion}

3.1. Synthesis. $N$-(Dimethylcarbamothioyl)-4-fluorobenzamide compound was synthesized in two steps. In the first step, 4fluorobenzoyl chloride reacted with an equimolar amount of 


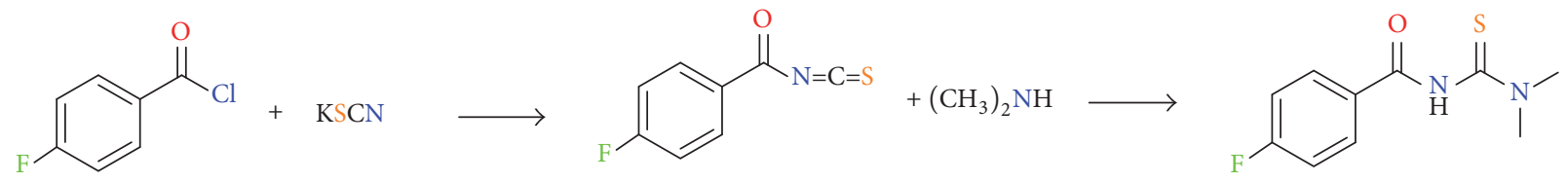<smiles>CN(C)C(=S)NC(=O)c1ccc(F)cc1</smiles>

SCHEME 1: Synthesis reaction of the ligand and metal complexes.

potassium thiocyanate in dry acetone. At the end of the reaction 4-fluorobenzoyl isothiocyanate appeared. In the second step, 4-fluorobenzoyl isothiocyanate reacted with dimethylamine in dry acetone solution to synthesize $N$ (dimethylcarbamothioyl)-4-fluorobenzamide [18, 19].

Complexes were obtained with good yield by stirring the appropriate metal acetate with two equivalents of $N$ (dimethylcarbamothioyl)-4-fluorobenzamide for 2 hours in methanol $[18,19]$. The reaction of complex is illustrated in Scheme 1. Ligand and its copper and nickel complex were characterized by different spectroscopic techniques including elemental analysis, IR, ${ }^{1} \mathrm{H}$ NMR spectroscopy, and single crystal X-ray diffraction study.

The FT-IR data of the prepared compounds are consistent with the proposed structures. In the FT-IR spectra of the ligand, the N-H stretching vibration is observed at $c a 3200 \mathrm{~cm}^{-1}$ as an intense broad band. This absorption band disappears upon metal complex formation. The delocalization of the $\nu \mathrm{C}=\mathrm{O}$ stretching vibration causes a negative shift. The $v$ $\mathrm{C}=\mathrm{O}$ stretching vibration can be observed in the ligand at $1695 \mathrm{~cm}^{-1}$, and the $v$ CO stretching vibration of the corresponding $\mathrm{Ni}(\mathrm{II})$ and $\mathrm{Cu}(\mathrm{II})$ complexes appears at 1445 and $1493 \mathrm{~cm}^{-1}$, respectively. This is in close agreement with other previously studied thiourea derivatives [18, 19, 29, 32-35].

The ${ }^{1} \mathrm{H}$ NMR spectra of all compounds are compatible with their expected structures. The ${ }^{1} \mathrm{H}$ NMR spectra of the ligands are consistent with their structures. In the ${ }^{1} \mathrm{H}$ NMR spectra, the N-H signal present in the ligand at $\delta 8.58 \mathrm{ppm}$ disappears in the complexes. The aryl proton signals are shifted to lower field $[18,19,29,32-35]$.

3.2. Crystal Structure Analysis. Crystals of the synthesized compounds suitable for single crystal X-ray diffraction analysis were obtained by recrystallization from dichloromethane: methanol $(1: 2, v: v)$ mixture at room temperature. The ORTEP views of bis $\left(N, N\right.$-dimethyl- $N^{\prime}-4$-fluorobenzoylthioureato) nickel(II) $\left(\mathrm{NiL}_{2}\right)$ and bis $(N, N$-dimethyl$N^{\prime}$-4-fluorobenzoylthioureato) copper(II) $\left(\mathrm{CuL}_{2}\right)$ with atom numbering schemes are depicted in Figures 4 and 5, respectively. Further details concerning data collection and refinement are given in Table 1 . Selected bond lengths and angles of $\mathrm{NiL}_{2}$ and $\mathrm{CuL}_{2}$ are listed in Table 2. The crystal structures (Figures 4 and 5) of the complexes confirm that the $N$-(dimethylcarbamothioyl)-4-fluorobenzamide ligand is a bidentate chelating ligand, coordinating with the copper or nickel atom through the thiocarbonyl and carbonyl groups [29, 32-35]. Both structures are isotypic with very related geometric parameters. The planes of the dimethylamino groups as well as those of the $p$-fluorophenyl rings are almost parallel to the carbamothioyl moieties as shown from the torsion angles $\mathrm{C}-\mathrm{N}-\mathrm{C}-\mathrm{N}$ and $\mathrm{O}-\mathrm{C}-\mathrm{C}-\mathrm{C}$ with average 1.3(5) and 1.5(2) $\AA$ and 4.9(5) and 6.4(3) $\AA$ for $\mathrm{NiL}_{2}$ and $\mathrm{CuL}_{2}$, respectively. The coordination around the metal centers deviates slightly from square planarity with S-M-S $85.26(6)^{\circ}$ and $88.62(2)^{\circ}$ and O$\mathrm{M}-\mathrm{O} 85.0(1)^{\circ}$ and $85.97(6)^{\circ}(\mathrm{Ni}$ and $\mathrm{Cu})$.

The lengths of the thiocarbonyl and carbonyl bonds are longer than the average for $\mathrm{C}=\mathrm{S}$ and $\mathrm{C}=\mathrm{O}$, while the $\mathrm{C}-\mathrm{N}$ bonds in the complex ring are all shorter than the average for C-N single bonds, indicating the expected delocalization in the chelate ring. All other bond lengths and angles are in expected ranges. Related structures are known from SOBRIL (bis(1,1-diethyl-3-(4-fluorobenzoyl)thiourea)-nickel(II)) [35] or FIKSUP (bis(N-4-fluorobenzoylpiperidine-1-carbothioimidato)-copper(II)) [36]. There are no intermolecular interactions shorter than Van der Waals radii.

3.3. Electrochemistry. The electrochemical behaviors of copper(II) and nickel(II) complexes have been investigated in aprotic solvents by cyclic voltammetry. According to the obtained results, both $\mathrm{Cu}(\mathrm{II})$ and $\mathrm{Ni}(\mathrm{II})$ complexes have shown electroactive properties. Cyclic voltammogram of $\mathrm{CuL}_{2}$ and $\mathrm{NiL}_{2}$ in dichloromethane are shown in Figure 6 . The results indicate that $\mathrm{CuL}_{2}$ undergoes one-electron reversible redox waves in potential range of 400 to $-400 \mathrm{mV}$. It can be seen from the cyclic voltammogram of $\mathrm{Cu}$ (II) complex in $\mathrm{DCM}$ at a scan rate of $0.1 \mathrm{~V} / \mathrm{s}$ that a well-defined redox 
TABLE 1: Crystal data and structure refinement for $\mathrm{NiL}_{2}$ and $\mathrm{CuL}_{2}$ complexes.

\begin{tabular}{|c|c|c|}
\hline Parameters & $\mathrm{NiL}_{2}$ & $\mathrm{CuL}_{2}$ \\
\hline Empirical formula & $\mathrm{C}_{20} \mathrm{H}_{20} \mathrm{~F}_{2} \mathrm{NiN}_{4} \mathrm{O}_{2} \mathrm{~S}_{2}$ & $\mathrm{C}_{20} \mathrm{H}_{20} \mathrm{~F}_{2} \mathrm{CuN}_{4} \mathrm{O}_{2} \mathrm{~S}_{2}$ \\
\hline Formula weight & 509.23 & 514.06 \\
\hline Temperature $(\mathrm{K})$ & $120(2)$ & $120(2)$ \\
\hline Wavelength & 0.71073 & 0.71073 \\
\hline Crystal system & Monoclinic & Monoclinic \\
\hline Space group & $P 2_{1} / c$ & $P 2_{1} / c$ \\
\hline$a(\AA)$ & $11.339(7)$ & $11.3504(16)$ \\
\hline$b(\AA)$ & $8.255(5)$ & $8.5070(12)$ \\
\hline$c(\AA)$ & 22.051(17) & $22.164(3)$ \\
\hline$\beta(\circ)$ & $103.934(18)$ & $103.828(3)$ \\
\hline Volume $\left(\AA^{3}\right)$ & $2003(2)$ & 2078.1(5) \\
\hline$Z$ & 4 & 4 \\
\hline Calculated density $\left(\mathrm{mg} / \mathrm{m}^{3}\right)$ & 1.689 & 1.643 \\
\hline Absorption coefficient $\left(\mathrm{mm}^{-1}\right)$ & 1.223 & 1.296 \\
\hline$F(000)$ & 1.048 & 1052 \\
\hline Crystal size $\left(\mathrm{mm}^{3}\right)$ & $0.47 \times 0.43 \times 0.02$ & $0.42 \times 0.33 \times 0.23$ \\
\hline Radiation & $\operatorname{MoK} \alpha$ & $\operatorname{MoK} \alpha$ \\
\hline$\Theta$ range for data collection & 1.85 to $27.87 \circ$ & 1.85 to $27.88^{\circ}$ \\
\hline Index ranges & $\begin{array}{l}-14 \leq h \leq 14 \\
-10 \leq k \leq 10 \\
-29 \leq l \leq 24\end{array}$ & $\begin{array}{c}14 \leq h \leq 14 \\
-11 \leq k \leq 10 \\
-25 \leq l \leq 29\end{array}$ \\
\hline Reflections collected & 17259 & 17633 \\
\hline Independent reflections & $4776\left[R_{\mathrm{int}}=0.1266\right]$ & $4953\left[R_{\mathrm{int}}=0.0279\right]$ \\
\hline Data/parameters & $4776 / 284$ & $4953 / 284$ \\
\hline Goodness-of-fit on $F^{2}$ & 0.947 & 1.057 \\
\hline Final $R$ indexes $(I \geq 2 \sigma(I))$ & $R 1=0.0554, \mathrm{w} R 2=0.1186$ & $R 1=0.0311, \mathrm{w} R 2=0.0792$ \\
\hline Final $R$ indexes (all data) & $R 1=0.0864, \mathrm{w} R 2=0.1285$ & $R 1=0.0378, \mathrm{w} R 2=0.0829$ \\
\hline Largest difference peak and hole $\left(e \cdot \AA^{-3}\right)$ & $0.926 /-0.892$ & $0.461 /-0.256$ \\
\hline
\end{tabular}

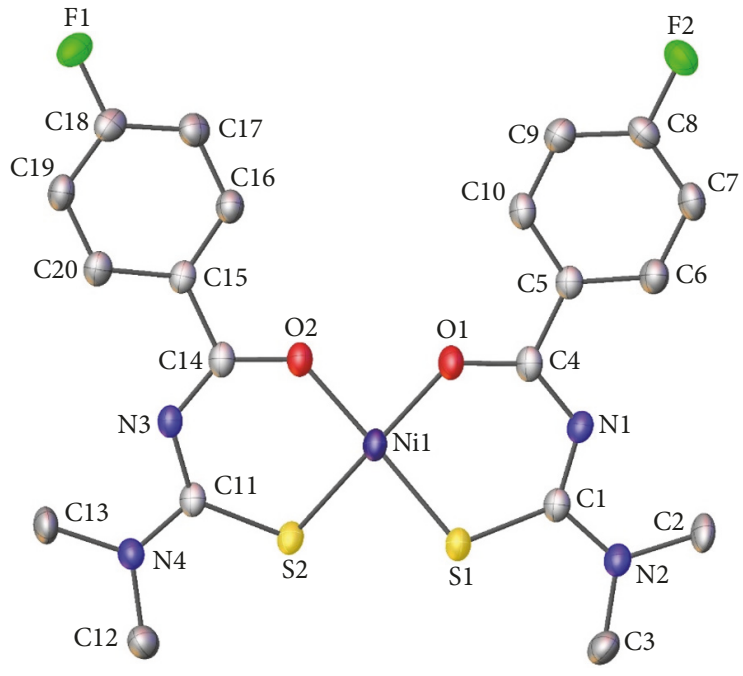

FIGURE 4: Molecular structure of $\mathrm{NiL}_{2}$ with anisotropic displacement ellipsoids drawn at $50 \%$ probability level. $\mathrm{H}$-atoms omitted for clarity.

process exists. The $\mathrm{Cu}(\mathrm{II})$ complex has exposed the observed reduction peak at $E_{\mathrm{pc}}=-0.085 \mathrm{~V}$ which indicates the formation of $\mathrm{Cu}(\mathrm{II}) / \mathrm{Cu}(\mathrm{I})$ and corresponding oxidation peak

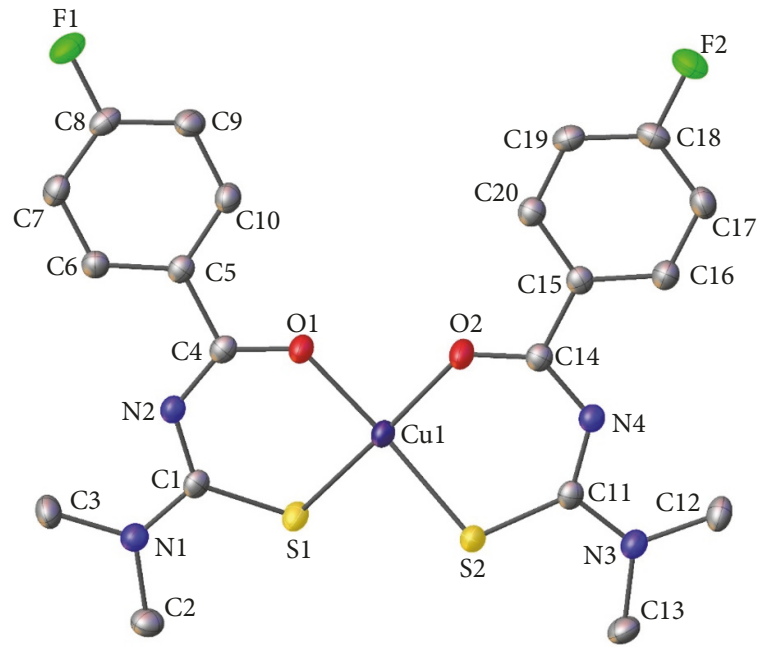

Figure 5: Molecular structure of $\mathrm{CuL}_{2}$ with anisotropic displacement ellipsoids drawn at $50 \%$ probability level. $\mathrm{H}$-atoms omitted for clarity.

at $E_{\mathrm{pa}}=0.025 \mathrm{~V}$ versus $\mathrm{Ag} / \mathrm{Ag}^{+}$indicates $\mathrm{C}(\mathrm{I}) / \mathrm{Cu}(\mathrm{II})$ couple [37-40]. The peak separation $\left(\Delta E_{p}\right)$ of this couple is found to be $0.110 \mathrm{~V}$ which is in accordance with the reversibility of 
TABLE 2: Bond lengths and angles for $\mathrm{NiL}_{2}$ and $\mathrm{CuL}_{2}$ complexes.

\begin{tabular}{|c|c|c|c|c|c|c|}
\hline Atom & Atom & Bond lengths, $\AA$ & Atom & Atom & Atom & Bond angles, $\circ$ \\
\hline \multicolumn{7}{|c|}{$\mathrm{NiL}_{2}$} \\
\hline $\mathrm{Ni}(1)$ & $\mathrm{O}(2)$ & $1.848(3)$ & $\mathrm{O}(2)$ & $\mathrm{Ni}(1)$ & $\mathrm{O}(1)$ & $85.05(12)$ \\
\hline $\mathrm{Ni}(1)$ & $\mathrm{O}(1)$ & $1.849(3)$ & $\mathrm{O}(2)$ & $\mathrm{Ni}(1)$ & $S(2)$ & 94.91(9) \\
\hline $\mathrm{Ni}(1)$ & $S(2)$ & $2.1241(15)$ & $\mathrm{O}(1)$ & $\mathrm{Ni}(1)$ & $S(2)$ & $174.84(9)$ \\
\hline $\mathrm{Ni}(1)$ & $S(1)$ & $2.1254(16)$ & $\mathrm{O}(2)$ & $\mathrm{Ni}(1)$ & $S(1)$ & $174.78(8)$ \\
\hline$S(2)$ & $\mathrm{C}(11)$ & $1.716(4)$ & $\mathrm{O}(1)$ & $\mathrm{Ni}(1)$ & $S(1)$ & $95.26(9)$ \\
\hline $\mathrm{N}(3)$ & $\mathrm{C}(14)$ & $1.305(4)$ & $S(2)$ & $\mathrm{Ni}(1)$ & $S(1)$ & $85.26(6)$ \\
\hline $\mathrm{N}(3)$ & $\mathrm{C}(11)$ & $1.324(4)$ & $\mathrm{C}(4)$ & $\mathrm{O}(1)$ & $\mathrm{Ni}(1)$ & $131.4(2)$ \\
\hline $\mathrm{O}(2)$ & $\mathrm{C}(14)$ & $1.264(4)$ & $\mathrm{C}(14)$ & $\mathrm{O}(2)$ & $\mathrm{Ni}(1)$ & $131.2(2)$ \\
\hline $\mathrm{N}(4)$ & $\mathrm{C}(11)$ & $1.329(4)$ & C(11) & $\mathrm{N}(4)$ & $\mathrm{C}(12)$ & $123.4(3)$ \\
\hline $\mathrm{N}(4)$ & $\mathrm{C}(12)$ & $1.445(5)$ & $\mathrm{C}(11)$ & $\mathrm{N}(4)$ & $\mathrm{C}(13)$ & $120.0(3)$ \\
\hline $\mathrm{N}(4)$ & $\mathrm{C}(13)$ & $1.458(5)$ & $\mathrm{C}(12)$ & $\mathrm{N}(4)$ & $\mathrm{C}(13)$ & $116.6(3)$ \\
\hline$C(14)$ & $\mathrm{C}(15)$ & $1.480(5)$ & $\mathrm{N}(3)$ & $\mathrm{C}(11)$ & $\mathrm{N}(4)$ & $115.1(3)$ \\
\hline $\mathrm{C}(15)$ & $\mathrm{C}(16)$ & $1.378(5)$ & $\mathrm{N}(4)$ & $\mathrm{C}(11)$ & $S(2)$ & $117.0(3)$ \\
\hline $\mathrm{C}(15)$ & $\mathrm{C}(20)$ & $1.383(5)$ & $\mathrm{C}(1)$ & $S(1)$ & $\mathrm{Ni}(1)$ & $107.56(13)$ \\
\hline $\mathrm{F}(1)$ & $\mathrm{C}(18)$ & $1.345(4)$ & $\mathrm{C}(11)$ & $S(2)$ & $\mathrm{Ni}(1)$ & $107.29(13)$ \\
\hline \multicolumn{7}{|c|}{$\mathrm{CuL} L_{2}$} \\
\hline $\mathrm{Cu}(1)$ & $\mathrm{O}(1)$ & $1.9232(13)$ & $\mathrm{O}(1)$ & $\mathrm{Cu}(1)$ & $\mathrm{O}(2)$ & $85.97(6)$ \\
\hline $\mathrm{Cu}(1)$ & $\mathrm{O}(2)$ & $1.9293(14)$ & $\mathrm{O}(1)$ & $\mathrm{Cu}(1)$ & $S(2)$ & $169.33(5)$ \\
\hline $\mathrm{Cu}(1)$ & $S(2)$ & $2.2349(5)$ & $\mathrm{O}(2)$ & $\mathrm{Cu}(1)$ & $S(2)$ & $93.81(4)$ \\
\hline $\mathrm{Cu}(1)$ & $S(1)$ & $2.2384(6)$ & $\mathrm{O}(1)$ & $\mathrm{Cu}(1)$ & $S(1)$ & $93.37(4)$ \\
\hline$S(1)$ & $\mathrm{C}(1)$ & $1.7360(18)$ & $\mathrm{O}(2)$ & $\mathrm{Cu}(1)$ & $S(1)$ & $170.37(5)$ \\
\hline $\mathrm{F}(1)$ & $\mathrm{C}(8)$ & $1.363(2)$ & $S(2)$ & $\mathrm{Cu}(1)$ & $S(1)$ & $88.62(2)$ \\
\hline $\mathrm{O}(1)$ & $\mathrm{C}(4)$ & $1.269(2)$ & $\mathrm{C}(4)$ & $\mathrm{O}(1)$ & $\mathrm{Cu}(1)$ & $131.65(12)$ \\
\hline $\mathrm{N}(1)$ & $\mathrm{C}(1)$ & $1.336(2)$ & $\mathrm{C}(1)$ & $\mathrm{N}(1)$ & $\mathrm{C}(2)$ & $123.31(16)$ \\
\hline $\mathrm{N}(1)$ & $\mathrm{C}(2)$ & $1.459(2)$ & $\mathrm{C}(1)$ & $\mathrm{N}(1)$ & $C(3)$ & $120.18(16)$ \\
\hline $\mathrm{N}(1)$ & $\mathrm{C}(3)$ & $1.470(2)$ & $\mathrm{C}(2)$ & $\mathrm{N}(1)$ & $\mathrm{C}(3)$ & $116.51(16)$ \\
\hline $\mathrm{N}(2)$ & $\mathrm{C}(4)$ & $1.318(2)$ & $\mathrm{C}(4)$ & $\mathrm{N}(2)$ & $\mathrm{C}(1)$ & $125.43(16)$ \\
\hline $\mathrm{N}(2)$ & $\mathrm{C}(1)$ & $1.343(2)$ & $\mathrm{N}(1)$ & $\mathrm{C}(1)$ & $\mathrm{N}(2)$ & $114.81(16)$ \\
\hline$C(4)$ & $C(5)$ & $1.498(2)$ & $\mathrm{N}(1)$ & $\mathrm{C}(1)$ & $S(1)$ & $117.42(14)$ \\
\hline$C(5)$ & C (10) & $1.392(3)$ & $\mathrm{N}(2)$ & $\mathrm{C}(1)$ & $S(1)$ & $127.71(14)$ \\
\hline$C(5)$ & $C(6)$ & $1.393(3)$ & $\mathrm{O}(1)$ & $\mathrm{C}(4)$ & $\mathrm{N}(2)$ & $130.40(17)$ \\
\hline
\end{tabular}

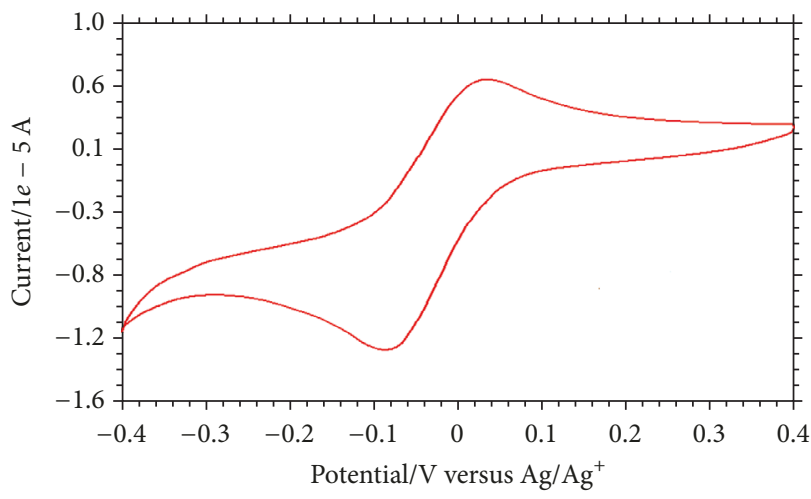

(a)

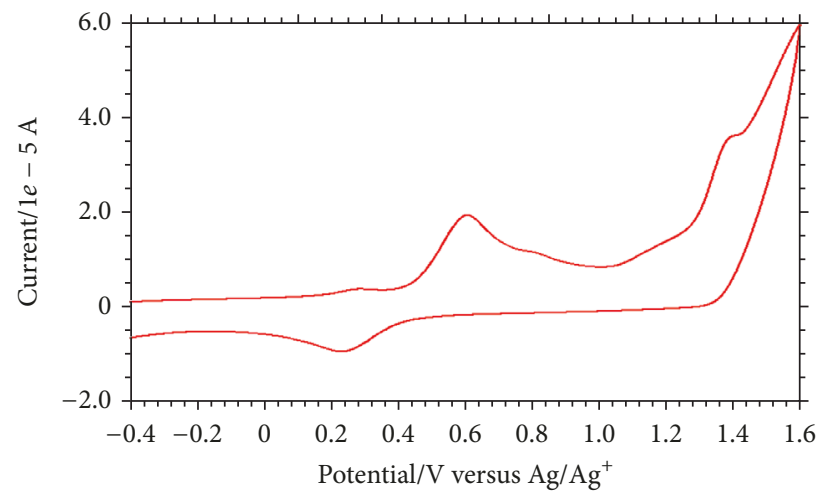

(b)

Figure 6: Cyclic voltammogram (a) of $\mathrm{CuL}_{2}$ and (b) of $\mathrm{NiL}_{2}$ in dichloromethane containing $0.1 \mathrm{M} \mathrm{TBAHFP.} \mathrm{Scan} \mathrm{rate} 100 \mathrm{mV} / \mathrm{s}$.

$\mathrm{Cu}(\mathrm{II}) / \mathrm{Cu}(\mathrm{I})$ couple. A similar study reported that thiourea $\mathrm{Cu}$ complexes showed the reduction of $\mathrm{Cu}(\mathrm{II}) / \mathrm{Cu}(\mathrm{I})$ redox system undergoing an irreversible process with peak separation $\left(\Delta E_{p}\right)$ of about $0.200 \mathrm{~V}$ [21]. Duan et al. indicated that some modified thiourea derivatives undergo one-electron quasi-reversible and reversible redox reactions [41]. $\mathrm{Ni}$ (II) complex shows a quasi-reversible redox wave and an irreversible oxidation peak in in potential range of -0.4 to $+1.6 \mathrm{~V}$. Cyclic voltammogram indicates that $\mathrm{Ni}$ (II) complex in DCM undergoes $\mathrm{Ni}(\mathrm{II}) / \mathrm{Ni}(\mathrm{III})$ oxidation at $E_{\mathrm{pa}}=0.59 \mathrm{~V}$ with corresponding reduction at $E_{\mathrm{pc}}=0.25 \mathrm{~V}[42,43]$. The peak separation $\left(\Delta E_{p}\right)$ is $0.34 \mathrm{~V}$ for $\mathrm{Ni}(\mathrm{II}) / \mathrm{Ni}(\mathrm{III})$ redox couple. 
$\mathrm{Ni}$ (II) complex also exhibits an irreversible oxidation peak at $+1.38 \mathrm{~V}$ that is considered to be ligand moiety.

\section{Conclusions}

In this work, $N$-(dimethylcarbamothioyl)-4-fluorobenzamide ligand and its $\mathrm{Ni}$ (II) and $\mathrm{Cu}(\mathrm{II})$ complexes have been synthesized and evaluated for their electroactive properties. The chemical structure of compounds was characterized by elemental analysis, FT-IR, and ${ }^{1} \mathrm{H}$ NMR spectroscopy techniques. When the FT-IR spectra of the compounds were examined, characteristic peaks $(v \mathrm{C}=\mathrm{O}, v \mathrm{C}-\mathrm{O}, v \mathrm{C}=\mathrm{S}, v$ $\mathrm{C}-\mathrm{S}$, and $\nu \mathrm{N}-\mathrm{H}$ stretching modes) were observed which should be present in similar benzoylthiourea derivatives such as 2,2-diphenyl- $N$-(dipropyl-carbamothioyl)acetamide, 2,2-diphenyl- $N$-(dibutyl-carbamothioyl)acetamide, bis (2,2-diphenyl- $N$-(diethylcarbamothioyl)acetamido)nickel(II), N,N-diethyl- $N^{\prime}$-benzoylthiourea, $N, N$-dipropyl- $N^{\prime}$-benzoylthiourea, cis-bis(N,N-dimethyl- $N^{\prime}$-4-chlorobenzoyl-thioureato)palladium(II), $N$-(dibenzylcarbamothioyl)-3-methylbutanamide, cis-bis[4-fluoro- $N$-(diethylcarbamothioyl)benzamido- $\left.\kappa^{2} \mathrm{O}, \mathrm{S}\right]$ platinum(II), $N$-(di-n-propyl carbamothioyl) cyclohexanecarboxamide, 4-chloro- $N$-[N-(6-methyl-2-pyridyl)carbamothioyl]benzamide, 4-bromo- $N$-(dimethylcarbamothioyl)benzamide, and bis(4-bromo- $N$-(dimethylcarbamothioyl)benzamido)nickel(II) which is consistent with the literature [1, 4$7,32,34,44,45]$. Besides these, the crystal and molecular structure of synthesized complexes were analyzed by X-ray single crystal diffraction method. The comparative analysis was performed with literature data. The structure of these compounds is consistent with the structure of other benzoylthiourea derivatives. The bond lengths and angles also agree well with other thiourea derivatives. The electrochemical behaviors of copper(II) and nickel(II) complexes have been investigated in aprotic solvents by cyclic voltammetry. $\mathrm{Cu}$ (II) complex showed reversible behavior in potential range of 400 to $-400 \mathrm{mV}$ while $\mathrm{Ni}$ (II) complex showed quasi-reversible behavior in potential of 1600 to $-400 \mathrm{mV}$. According to the obtained results, both $\mathrm{Cu}(\mathrm{II})$ and $\mathrm{Ni}$ (II) complexes have shown electroactive properties.

\section{Disclosure}

A part of this work was presented as a poster (P-261) at the 5th National Inorganic Chemistry Congress 2015 in Mersin, Turkey.

\section{Conflicts of Interest}

The authors declare that they have no conflicts of interest.

\section{Acknowledgments}

This academic work was linguistically supported by the Mersin Technology Transfer Office Academic Writing Center of Mersin University. This study was supported by the Research Fund of Mersin University in Turkey with Project no. BAP-2015-AP4-1198.

\section{Supplementary Materials}

Crystallographic data (excluding structure factors) for the structures reported in this paper have been deposited with the Cambridge Crystallographic Data Centre as Supplementary Publication no. CCDC-1457502 for $\mathrm{NiL}_{2}$ and no. 1459297 for $\mathrm{CuL}_{2}$. Copies of available material can be obtained free of charge via https://www.ccdc.cam.ac.uk/structures/, by emailing data_request@ccdc.cam.ac.uk, or contacting the Cambridge Crystallographic Data Centre, 12, Union Road, Cambridge CB2 1EZ, UK, fax: +44 1223 336033. (Supplementary Materials)

\section{References}

[1] D. S. Mansuroglu, H. Arslan, U. Flörke, and N. Külcü, "Synthesis and characterization of nickel and copper complexes with 2,2diphenyl-N-(alkyl(aryl)carbamothioyl)acetamide: the crystal structures of HL1 and cis-[Ni(L1)2]," Journal of Coordination Chemistry, vol. 61, no. 19, pp. 3134-3146, 2008.

[2] K. R. Koch, "New chemistry with old ligands: N-alkyl- and N,Ndialkyl-N'-acyl(aroyl)thioureas in co-ordination, analytical and process chemistry of the platinum group metals," Coordination Chemistry Reviews, vol. 216-217, pp. 473-488, 2001.

[3] R. Shardin, S. S. Tan, and M. B. Kassim, "Synthesis and structural characterization of N-bromobenzoyl- $\mathrm{N}^{\prime}$-(1,10-phenanthrolin-5-yl)thiourea derivatives," Malaysian Journal of Analytical Sciences, vol. 21, no. 1, pp. 60-71, 2017.

[4] N. Özpozan, H. Arslan, T. Özpozan, M. Merdivan, and N. Külcü, "Thermal decomposition kinetics of some metal complexes of N,N-diethyl-N' ${ }^{\prime}$-benzoylthiourea," Journal of Thermal Analysis and Calorimetry, vol. 61, no. 3, pp. 955-965, 2000.

[5] N. Ozpozan, T. Ozpozan, H. Arslan, F. Karipçin, and N. Külcü, "Thermal behaviours of $\mathrm{Co}(\mathrm{II}), \mathrm{Ni}(\mathrm{II}), \mathrm{Cu}(\mathrm{II})$ ), and $\mathrm{Pb}$ (II) complexes of N,N-dipropyl- $\mathrm{N}^{\prime}$-benzoylthiourea," Thermochimica Acta, vol. 336, no. 1-2, pp. 97-103, 1999.

[6] H. Arslan, D. Vanderveer, F. Emen, and N. Külcü, "Crystal structure of cis-bis(N,N-dimethyl- $\mathrm{N}^{\prime}$-4-chlorobenzoyl- thioureato)palladium(II), Pd(C10H10ClN2OS)2," Zeitschrift fur Kristallographie - New Crystal Structures, vol. 218, pp. 511-512, 2003.

[7] G. Binzet, F. M. Emen, U. Flörke, T. Yȩilkaynak, N. Külcü, and H. Arslan, "4-Chloro-N-[N-(6-methyl-2-pyridyl)carbamothioyl]benzamide," Acta Crystallographica Section E: Structure Reports Online, vol. 65, no. 1, p. o81, 2009.

[8] X. Xu, X. Qian, Z. Li, Q. Huang, and G. Chen, "Synthesis and insecticidal activity of new substituted $\mathrm{N}$-aryl- $\mathrm{N}^{\prime}$ benzoylthiourea compounds," Journal of Fluorine Chemistry, vol. 121, no. 1, pp. 51-54, 2003.

[9] S. Saeed, N. Rashid, P. G. Jones, M. Ali, and R. Hussain, "Synthesis, characterization and biological evaluation of some thiourea derivatives bearing benzothiazole moiety as potential antimicrobial and anticancer agents," European Journal of Medicinal Chemistry, vol. 45, no. 4, pp. 1323-1331, 2010.

[10] J. P. Barolli, P. I. S. Maia, L. Colina-Vegas et al., "Heteroleptic tris-chelate ruthenium(II) complexes of N,N-disubstituted-N' acylthioureas: synthesis, structural studies, cytotoxic activity and confocal microscopy studies," Polyhedron, vol. 126, pp. 3341, 2017. 
[11] D. Erşen, M. Ülger, S. Mangelinckx, M. Gemili, E. Şahin, and Y. Nural, "Synthesis and anti(myco)bacterial activity of novel 5,5diphenylpyrrolidine $\mathrm{N}$-aroylthiourea derivatives and a functionalized hexahydro-1H-pyrrolo[1,2-c]imidazole," Medicinal Chemistry Research, vol. 26, no. 9, pp. 2152-2160, 2017.

[12] C. K. Özer, H. Arslan, D. VanDerveer, and N. Külcü, "Synthesis and characterization of $\mathrm{N}$-(arylcarbamothioyl)- cyclohexanecarboxamide derivatives: the crystal structure of N-(naphthalen-1-ylcarbamothioyl)cyclohexanecarboxamide," Molecules, vol. 14, no. 2, pp. 655-666, 2009.

[13] M. Gemili, H. Sari, M. Ulger, E. Sahin, and Y. Nural, "Pt(II) and $\mathrm{Ni}(\mathrm{II})$ complexes of octahydropyrrolo[3,4-c]pyrrole Nbenzoylthiourea derivatives: synthesis, characterization, physical parameters and biological activity," Inorganica Chimica Acta, vol. 463, pp. 88-96, 2017.

[14] S. S. Bozkurt and M. Merdivan, "Solid phase extraction of gold(III) on silica gel modified with benzoylthiourea prior to its determination by flame atomic absorption spectrometry," Environmental Modeling \& Assessment, vol. 158, no. 1-4, pp. 1521, 2009.

[15] S. Ayata, I. Kaynak, and M. Merdivan, "Solid phase extractive preconcentration of silver from aqueous samples," Environmental Modeling \& Assessment, vol. 153, no. 1-4, pp. 333-338, 2009.

[16] D. Totur, S. S. Bozkurt, and M. Merdivan, "Use of pyrocatechol violet modified sodium dodecyl sulfate coated on alumina for separation and preconcentration of uranium(VI)," Journal of Radioanalytical and Nuclear Chemistry, vol. 292, no. 1, pp. 321327, 2012.

[17] S. S. Hassan, M. M. Shoukry, R. N. Shallan, and R. van Eldik, "Synthesis, characterization, speciation and biological studies on metal chelates of 1-benzoyl(1,2,4-triazol-3-yl)thiourea," Journal of Coordination Chemistry, vol. 70, no. 10, pp. 1761-1775, 2017.

[18] G. Binzet, Synthesis and characterization of benzoylthiourea derivatives and their metal complexes, Mersin University, Mersin, Turkey, 2009.

[19] G. Binzet, G. Kavak, N. Külcü, S. Özbey, U. Flörke, and H. Arslan, "Synthesis and characterization of novel thiourea derivatives and their nickel and copper complexes," Journal of Chemistry, vol. 2013, Article ID 536562, 9 pages, 2013.

[20] F. A. Saad, N. J. Buurma, A. J. Amoroso, J. C. Knight, and B. M. Kariuki, "Co-ordination behaviour of a novel bisthiourea tripodal ligand: structural, spectroscopic and electrochemical properties of a series of transition metal complexes," Dalton Transactions, vol. 41, no. 15, pp. 4608-4617, 2012.

[21] A. Mohamadou, I. Déchamps-Olivier, and J.-P. Barbier, "Synthesis of N-morpholine or N,N-diethyl, $\mathrm{N}^{\prime}$-monosubstituted benzoyl thiourea copper complexes: characterization and electrochemical investigations," Polyhedron, vol. 13, no. 24, pp. 32773283, 1994.

[22] A. Mohamadou, I. Déchamps-Olivier, and J.-P. Barbier, "Copper, nickel and cobalt complexes with N,N-disubstituted'benzoyl thioureas," Polyhedron, vol. 13, no. 9, pp. 1363-1370, 1994.

[23] I. Déchamps-Olivier, E. Guillon, A. Mohamadou, and J.-P. Barbier, "Coordination of nickel and cobalt with $\mathrm{N}$-morpholine or N,N-diethyl, N'-monosubstituted benzoyl thioureas," Polyhedron, vol. 15, no. 20, pp. 3617-3622, 1996.

[24] E. Guillon, A. Mohamadou, I. Déchamps-Olivier, and J.-P. Barbier, "Synthesis and characterization of copper, nickel and cobalt complexes with $\mathrm{N}$-disubstituted, $\mathrm{N}^{\prime}$-ethoxy carbonyl thioureas," Polyhedron, vol. 15, no. 5-6, pp. 947-952, 1996.
[25] J. Losada, I. Del Peso, and L. Beyer, "Synthesis, electrochemical properties and electro-oxidative polymerization of copper(II) and nickel(II) complexes with $\mathrm{N}^{\prime}$-benzoylthiourea ligands containing pyrrole groups," Transition Metal Chemistry, vol. 25, no. 1, pp. 112-117, 2000.

[26] K.-H. Lubert, L. Beyer, and M. Guttmann, "Voltammetric study of N-benzoylthiourea and its $\mathrm{N}^{\prime}, \mathrm{N}^{\prime}$-disubstituted derivatives as possible electrode modifiers," Collection of Czechoslovak Chemical Communications, vol. 64, no. 12, pp. 1937-1952, 1999.

[27] O. Estévez-Hernández, J. L. Hidalgo-Hidalgo de Cisneros, E. Reguera, and I. Naranjo-Rodríguez, "On the complex formation of $\mathrm{CdCl} 2$ with 1-furoylthioureas: preconcentration and voltammetric behavior of $\mathrm{Cd}(\mathrm{II})$ at carbon paste electrodes modified with 3-monosubstituted and 3,3-disubstituted derivatives," Sensors and Actuators B: Chemical, vol. 120, no. 2, pp. 766-772, 2007.

[28] N. Gunasekaran, P. Jerome, S. W. Ng, E. R. T. Tiekink, and R. Karvembu, "Tris-chelate complexes of cobalt(III) with N[di(alkyl/aryl)carbamothioyl] benzamide derivatives: Synthesis, crystallography and catalytic activity in TBHP oxidation of alcohols," Journal of Molecular Catalysis A: Chemical, vol. 353354, pp. 156-162, 2012.

[29] C. K. Ozer, H. Arslan, D. Vanderveer, and G. Binzet, "Synthesis and characterization of N-(alky(aryl)carbamothioyl) cyclohexanecarboxamide derivatives and their $\mathrm{Ni}(\mathrm{II})$ and $\mathrm{Cu}(\mathrm{II})$ complexes," Journal of Coordination Chemistry, vol. 62, no. 2, pp. 266-276, 2009.

[30] G. M. Sheldrick, "A short history of SHELX," Acta Crystallographica Section A: Foundations of Crystallography, vol. 64, no. 1, pp. 112-122, 2008.

[31] G. M. Sheldrick, "Crystal structure refinement with SHELXL," Acta Crystallographica Section C: Crystal Structure Communications, vol. 71, pp. 3-8, 2015.

[32] G. Binzet, N. Külcü, U. Flörke, and H. Arslan, "Synthesis and characterization of $\mathrm{Cu}(\mathrm{II})$ and $\mathrm{Ni}$ (II) complexes of some 4-bromo-N-(di(alkyl/aryl)carbamothioyl) benzamide derivatives," Journal of Coordination Chemistry, vol. 62, no. 21, pp. 3454-3462, 2009.

[33] H. Arslan, U. Flörke, and N. Külcü, “The crystal and molecular structure of 1-(biphenyl-4-carbonyl)-3-p-tolyl- thiourea," Acta Chimica Slovenica, vol. 51, no. 4, pp. 787-792, 2004.

[34] I. Gumus, C. K. Ozer, D. Vanderveer, and H. Arslan, "Crystal structure of cis-copper(II) complex with $\mathrm{N}$-(di-n-propylcarbamothioyl)cyclohexanecarboxamide ligand," European Journal of Chemistry, vol. 7, no. 4, pp. 416-420, 2016.

[35] Y.-M. Zhang, H.-X. Pang, C. Cao, and T.-B. Wei, "Synthesis and crystal structure of $\mathrm{Cu}(\mathrm{I})$ and $\mathrm{Ni}(\mathrm{II})$ complexes of 1,1diethyl-3-(4-fluorobenzoyl)-thiourea," Journal of Coordination Chemistry, vol. 61, no. 10, pp. 1663-1670, 2008.

[36] H. Liu, W. Yang, W. Zhou, Y. Xu, J. Xie, and M. Li, "Crystal structures and antimicrobial activities of copper(II) complexes of fluorine-containing thioureido ligands," Inorganica Chimica Acta, vol. 405, pp. 387-394, 2013.

[37] H. Lin, X. Wang, H. Hu, B. Chen, and G. Liu, "A novel copper(II) complex constructed with mixed ligands of biphenyl-4, $4^{\prime}$ dicarboxylic acid (H2bpdc) and dipyrido[3,2-d:2 $2^{\prime}, 3^{\prime}$-f] quinoxaline (Dpq): synthesis, structure, electrochemistry and electrocatalysis," Solid State Sciences, vol. 11, no. 3, pp. 643-650, 2009.

[38] M. H. Habibi, R. Mokhtari, M. Mikhak, M. Amirnasr, and A. Amiri, "Synthesis, spectral and electrochemical studies of $\mathrm{Cu}$ (II) and $\mathrm{Ni}(\mathrm{II})$ complexes with new $\mathrm{N} 2 \mathrm{O} 2$ ligands: a new precursor capable of depositing copper nanoparticles using 
thermal reduction," Spectrochimica Acta Part A: Molecular and Biomolecular Spectroscopy, vol. 79, no. 5, pp. 1524-1527, 2011.

[39] X.-L. Wang, H.-Y. Lin, G.-C. Liu, H.-Y. Zhao, and B.-K. Chen, "Synthesis, structures, electrochemistry and electrocatalysis of two novel copper(II) complexes constructed with aromatic polycarboxylates and dipyrido[3,2-d:2',3' -f] quinoxaline," Journal of Organometallic Chemistry, vol. 693, no. 16, pp. 2767-2774, 2008.

[40] X. Wang, H. Zhao, H. Lin, G. Liu, J. Fang, and B. Chen, "Renewable new copper complex bulk-modified carbon paste electrode: preparation, electrochemistry, and electrocatalysis," Electroanalysis, vol. 20, no. 10, pp. 1055-1060, 2008.

[41] X.-E. Duan, X.-H. Wei, H.-B. Tong, S.-D. Bai, Y.-B. Zhang, and D.-S. Liu, "Ferrocene-modified pyrimidinyl acyl-thiourea derivatives: synthesis, structures and electrochemistry," Journal of Molecular Structure, vol. 1005, no. 1-3, pp. 91-99, 2011.

[42] K. Das, A. Datta, S. Roy et al., "Doubly phenoxo-bridged M$\mathrm{Na}(\mathrm{M}=\mathrm{Cu}(\mathrm{II}), \mathrm{Ni}(\mathrm{II}))$ complexes of tetradentate Schiff base: structure, photoluminescence, EPR, electrochemical studies and DFT computation," Polyhedron, vol. 78, pp. 62-71, 2014.

[43] S. Kundu, A. K. Pramanik, A. S. Mondal, and T. K. Mondal, "Ni(II) and $\mathrm{Pd}(\mathrm{II})$ complexes with new N,O donor thiophene appended Schiff base ligand: Synthesis, electrochemistry, X-ray structure and DFT calculation," Journal of Molecular Structure, vol. 1116, pp. 1-8, 2016.

[44] I. Gumus, S. Gonca, B. Arslan, E. Keskin, U. Solmaz, and H. Arslan, "N-(Dibenzylcarbamothioyl)-3-methylbutanamide: crystal structure, Hirshfeld surfaces and antimicrobial activity," European Journal of Chemistry, vol. 8, no. 4, pp. 410-416, 2017.

[45] I. Gumus, U. Solmaz, O. Celik, G. Binzet, G. K. Balc1, and H. Arslan, "Synthesis, characterization and crystal structure of cis-bis[4-fluoro-N-(diethylcarbamothioyl)benzamido$\kappa 2 \mathrm{O}, \mathrm{S}]$ platinum(II)," European Journal of Chemistry, vol. 6, no. 3, pp. 237-241, 2015. 

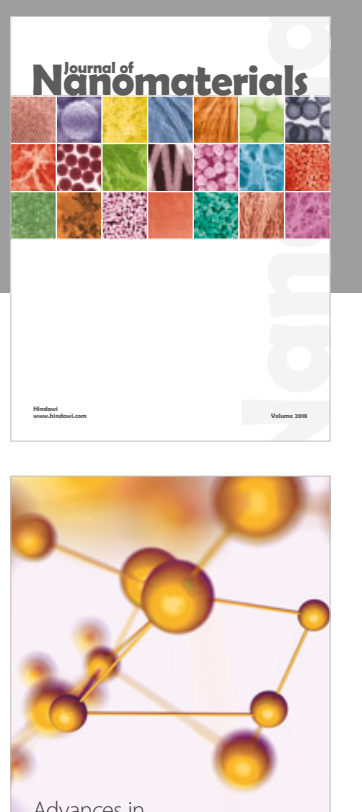

Physical Chemistry
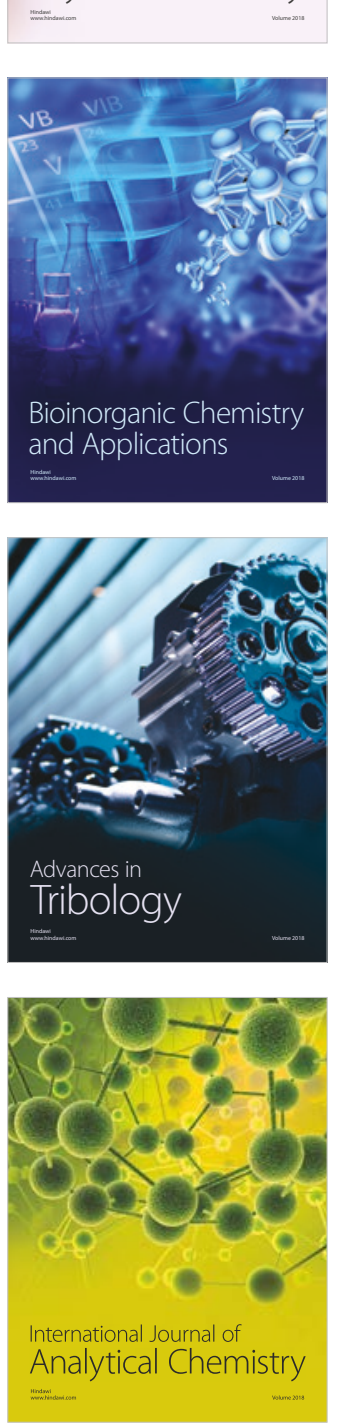

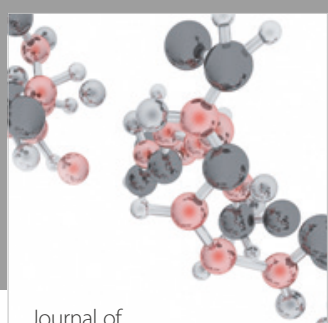

Analytical Methods

in Chemistry

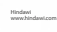

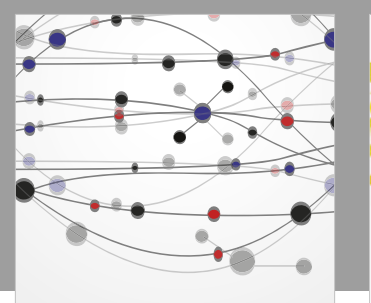

The Scientific World Journal

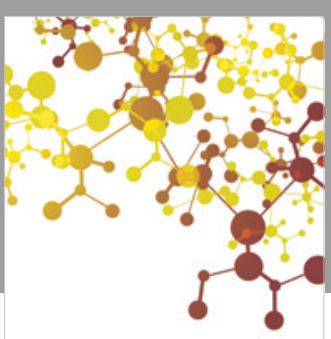

Journal of

Applied Chemistry
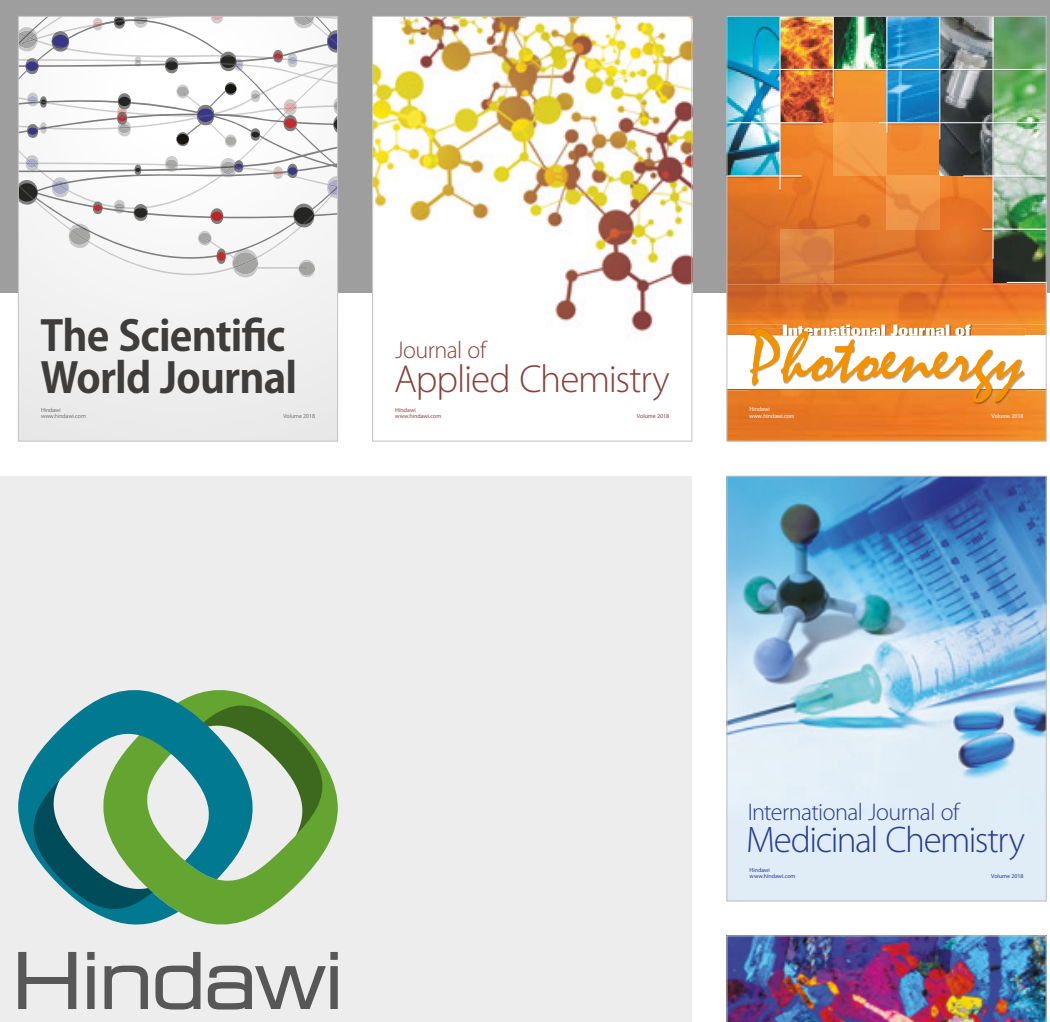

Submit your manuscripts at

www.hindawi.com
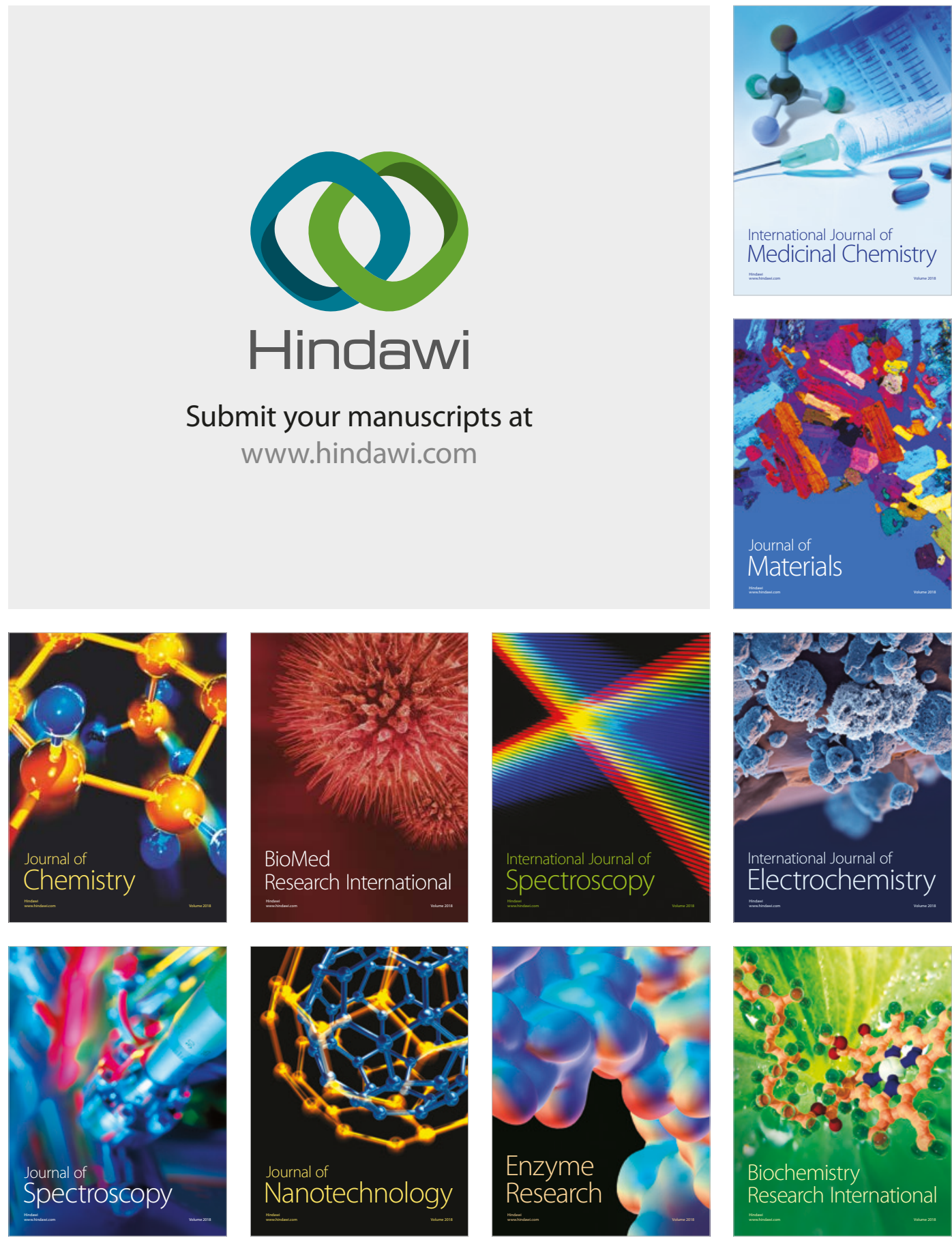
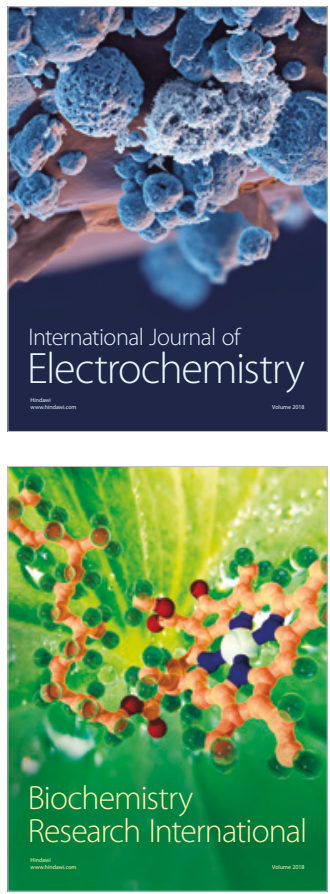